\title{
Should we bother to practice ecological responsibility?
}

\section{Being a snapshot of the slow but ongoing walk of a human toward more-than-humanness including a review of $A$ Book of Ecological Virtues: Living Well in the Anthropocene}

\section{Mitch Bleier ${ }^{1}$}

Received: 28 December 2020 / Accepted: 13 February 2021 / Published online: 18 July 2021 (c) The Author(s), under exclusive licence to Springer Nature B.V. 2021

\begin{abstract}
Are green goals and eco-sensitivity manifestations of delusional human exceptionalism? In this paper I grapple with the question of why/if humans should/must address environmental issues (both local and global) created or exacerbated by human activity. This question can be framed in terms of (a) whether human activity is as natural as that of other organisms and carries with it similar responsibilities, and (b) whether our activity, natural or not, matters in the very long term. It is a consideration of our responsibilities to ourselves, future generations, other organisms, and the earth itself. The recently published A Book of Ecological Virtues: Living Well in the Anthropocene is explored as it challenges the author of this article to confront these issues and their bearing on his and others' behaviors and actions vis à vis the earth and its inhabitants.

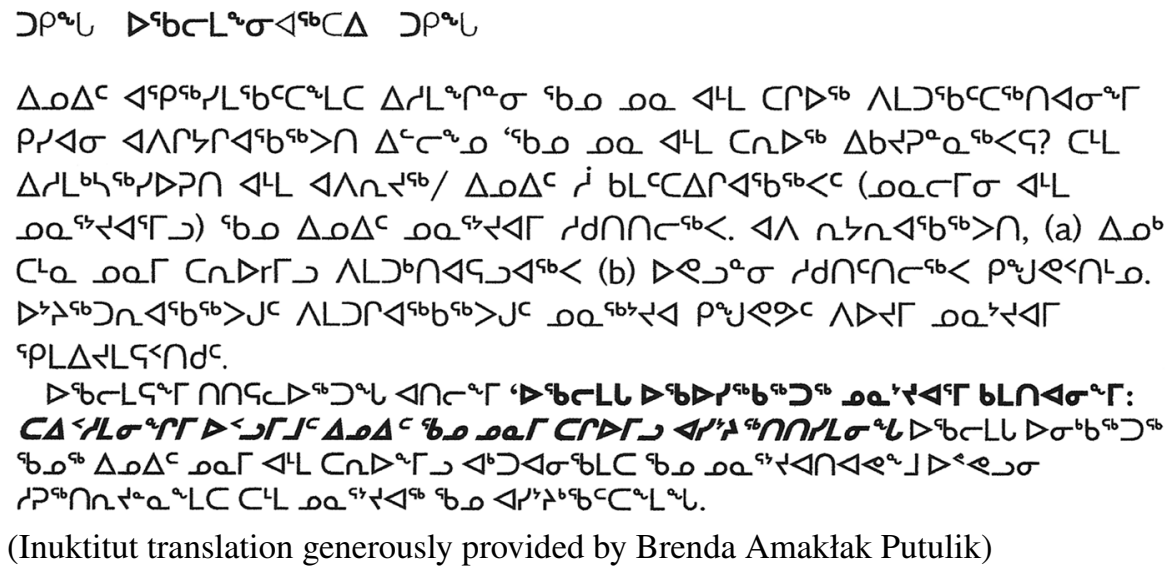

(Inuktitut translation generously provided by Brenda Amakłak Putulik)

Lead Editor: K. Tobin.

This manuscript is part of the special issue Contemplative Inquiry, Well-being and Science Education, guest edited by Kenneth Tobin.

Extended author information available on the last page of the article 
Keywords Ecological virtue - Sustainability - Environmental science education - Posthuman $\cdot$ Anthropocene

\section{Progress?}

As a child in New York City in the 1970s, I remember almost no color. The sky and buildings were a rainbow of grays almost all the time. The word smog coined in the early twentieth century to describe a combination of smoke and fog (Journal of the American Medical Association, 1905), later in the twentieth century came to mean photochemical smog - a phenomenon where gases arising from human activity react with sunlight to produce toxic atmospheric pollutants. The phenomenon was so ubiquitous and persistent that, even though there were many days that we were instructed to stay indoors unless absolutely necessary in order to preserve our health, the condition was normalized and accepted to the point that it even became fodder for jokes on late-night television. The systems that we had created to make life, not merely tolerable, but enjoyable frequently broke down. Garbage strikes would quickly line the streets with mountains of plastic bags filled with the debris of our daily lives. Even when collection and removal of refuse from city streets was accomplished, coastal landfills grew into landforms achieving the highest altitudes that could be found along the edges of the east coast of the United States as well as in other parts of the industrialized/industrializing world. Cars and trucks, coal-fired boilers, and incinerators added particulates and pollutants to the air. City buses generated clouds of thick, black smoke as part of their normal operation. I can still remember the smell (oddly, with some nostalgic fondness). Waterways and wetlands inundated with agricultural runoff, dumping-legal and illegal, and effluent from industrial processes, became toxic to their inhabitants and to all that depended on them for food and water. On more than a few occasions, rivers (most famous among them, the Cuyahoga River) laden with petrochemicals and oil actually caught on fire. Lorraine Boissoneault (2019) writes that the pollution of the Cuyahoga was a "badge of honor" and a "sign of success":

For more than a century, the Cuyahoga River had been prime real estate for various manufacturing companies. Everyone knew it was polluted, but pollution meant industry was thriving, the economy was booming, and everyone had jobs.

Neil Maher (2019) observes that, while the fires on the Cuyahoga sparked environmental awareness and "helped to jump-start the modern environmental movement" in the early 1970 s, environmental malfeasance also was inextricably linked to social and political inequities and tribulations:

Cleveland, like the river flowing through it, was also polluted. Its poorest neighborhoods - which were rife with dirty air, garbage-strewn streets and unhealthy housing - caught fire several times during the long hot summers of the late 1960s, as happened in cities all over the northern United States.

At that time (the late 1960s and 1970s), the injurious "side" effects of the green revolution-the use of chemical fertilizers and biocides to produce crops of plants and animals in the noble cause of feeding the planet and ending famine and, consequently, increasing human life expectancies and the world's population-were yet to clearly and indisputably manifest themselves. Post-war Europe no longer suffering the deprivation left in the aftermath of WWII, began to thrive as did North America. The promise of progress-political 
and economic - in post-colonial Africa and Asia seemed achievable. But images emerged of starvation in Appalachia, Ethiopia, Biafra, Bangladesh and other places resulting from a range of both natural and human activity, agricultural practices and political vagaries. We learned to live in a soup of swill that was our air and our water. These circumstances became normal and, although people were aware that these conditions were sub-ideal to say the least, they were accepted by many as simply the way things were-the price of our modern lifestyles. Godfrey Reggio's (1982) film Koyaanisqatsi: Life out of balance provides a magnificent depiction of these and worse conditions emerging from the uneasy and increasingly out of balance relationships between humans and their environments. It presents "an apocalyptic vision of the collision of two different worlds-urban life and technology versus the environment" (Koyaanisqatsi 2020). To ever increasing numbers of people, it began to become apparent that mining, commercial fishing, agriculture, travel, construction, and human reproduction were no longer pursuits that local environments or the planet itself could long endure unchanged.

In the previous paragraph, I used the phrase "natural and human activity." I would like to unpack this a little. Much human intellectual activity is, by definition, anthropocentric. We tend to center ourselves. We divide the animals of the earth into vertebrates and invertebrates. Belonging to the much smaller and more insignificant group, we elevate vertebrates to a status above our brother and sister animals, and certainly above plants, fungi and protozoa. We ask questions like: What good are mosquitoes? and Can't we eradicate them? We ask these questions even though there are countless examples of humans, employing reductionist cause-and-effect approaches to our problems that produce unexpected and undesirable results.

\section{Be fruitful and multiply: the non-human consequences of human whimsy, carelessness, industry, ego, and progress}

Humans, as they explore, migrate, and go about the business of being human bring about changes large and small to their immediate environments and broader and even global influences on their fellow organisms and the planet itself.

Humans have introduced European wild rabbits to Australia for sport hunting, kudzu to control soil erosion in the United States, cane toads to control sugarcane pests in the South Pacific and the Caribbean, etc.-always with unanticipated (but not necessarily unanticipatable) consequences, sometimes devastating ones. Of course, humans also have been the vectors of unintended introduction of non-native and invasive species around the world, e.g., the Norway rat, breadfruit, and the zebra mussel. While such species have had their impact on local habitats, it is the economic devastation that has caught the attention of both citizens and governments where they have joined the complex assemblages of organisms and abiotic components of various environments. Following are some examples.

\section{European starling (Sturnus vulgaris)}

The European starling is most common in Europe and North America, although there are significant populations in Australia, and southern Africa. The North American population (currently numbering about 200,000,000) are thought all to have descended from one hundred individuals released in Central Park in New York City in 1890 and 1891 by Eugene Schiefflin and members of the American Acclimatization Society (New York Times 1877), 
a group of prominent citizens including scientists, naturalists, and conservationists founded in New York City in 1871 . Their charter included the goal to introduce "such foreign varieties of the animal and vegetable kingdom as may be useful or interesting" (American Acclimatization Society, New York 1871). Their purpose? A sometimes-disputed account contends that the release was part of a project to introduce in the United States every bird mentioned in the writings of William Shakespeare. Although the members of the society had no way of knowing it ahead of time, the starlings proved to be a very successful invasive species rapidly spreading across the continent and becoming and remaining to the present day a negative environmental and economic factor, outcompeting native species and effecting costly crop damage (Siebert 2020). This phenomenon was repeated with the release of other birds as well, most notably the English sparrow. Other projects that have had varying degrees of impact, introduced plants and animals mentioned in the works of Shakespeare or in the Bible and for a variety of whimsical, practical, and other purposes (Todd 2001).

\section{Hippopotamus (Hippopotamus amphibius)}

The international cocaine trafficker Pablo Escobar imported a small herd of hippopotamuses for a personal zoo he built on his Colombian estate. Upon his death in 1993, four of those hippos were abandoned and began a feral existence during which they multiplied and dispersed into the environment. Today, they are estimated to number as many as one hundred individuals, and it is estimated that, by 2050, the population may grow as large as 800 to 5000 individuals (Wilcox 2020). Today, scientists and the Columbian government are in a quandary about what to do with these animals that seem to be thriving in their new home. Some argue that they are non-native; they wreak havoc in the environment and we cannot know what the long-term effects of their presence will be (Kremer 2014). Others claim that the hippos may be re-occupying a niche vacated as Pleistocene hunters brought on the extinction of local megafauna (Elbein 2020).

\section{Norway rat aka brown rat (Rattus norvegicus)}

The rat, a common companion of city dwellers worldwide, may have had its origins in Asia more than 600,000 years ago (Teng et al. 2017). As humans plied the seas and transported goods between continents, the rat found its way aboard vessels of all types and has insinuated itself into most of the geographic locations into which humans have insinuated themselves. Now ubiquitous presences in cities around the globe, humans and Norway rats are cohabitants whose fortunes are not-infrequently intertwined. These rodents are a major health and economic concern in many parts of the world and are a common sight in major cities. They have proven to be difficult to control and impossible to eradicate.

\section{Corn (Zea mays)}

One of the major crops that humans grow is a grass known in the United States as corn and elsewhere as maize. It, along with a relatively small number of other plants and animals are counted among the species domesticated by humans. The term domestication generally refers to organisms that consciously or incidentally have been significantly altered from their wild ancestors to meet the needs of humans. Domesticated plants and animals have, over many 
generations been made dependent on human agency in order to survive and reproduce. Michael Pollan (2006) proposes in his book The Omnivore's Dilemma that a case can easily be made that corn has domesticated humans. It has expanded its range to grasslands and other temperate ecosystems on every inhabited continent. Humans spend inordinate amounts of energy and effort modifying vast areas of land into corn habitat. They plant seeds, tend developing plants and protect them from animals bent on eating them and plants that might compete with them for resources. When the fruits of corn are mature, humans and their domesticated animals are rewarded with food and they, in turn, collect and store seeds for next year's crop.

These are but a few examples of the consequences of humans tinkering with the distribution of species around the planet. But how are these examples different from the ways in which organisms are naturally distributed via wind, ocean currents, within the digestive tracts of birds, or via the long-term motion of continents due to plate tectonics? What about humans and our activities is unnatural? Is this idea simply a manifestation of the dubious premise of human exceptionalism or is there something, at a fundamental level, that distinguishes humans from all other living things? Notwithstanding tenets of many non-Western (The term nonWestern privileges a small hegemonic component of humanity in the same way that vertebrates occupy an arbitrarily central position in the anthropocentric worldview) knowledge systems, humans set themselves apart from, dominant over, and often in opposition to nature. Is it tool use that sets us apart? No. Transmission of cultural knowledge from one generation to the next? No. Awareness of our own mortality? Not sure. Whatever it is, is debatable. I am left wondering why/how/if we are not merely a natural component of the natural world-petroleum, plastic, pollution and all. I have been comfortable for years not having an answer to this question, but accelerating climate change and the reading of the recently published, A Book of Ecological Virtues: Living Well in the Anthropocene (Bai, Chang, and Scott 2020a) has allowed (compelled) me to revisit the dissonance that the thought engenders in me, allowed me to bathe in these ideas and to rethink my responses to and responsibilities for the human impact on the planet that is the home to all of the entities that are here-human and nonhuman, living, and non-living alike.

I have spent much of my professional career in the cocoon of Western science with its positivist notions of objectivity and universality in the pursuit of Truth. As I have come to be aware of, accept, and incorporate understandings of the world through and around Indigenous, religious, and contemplative ways of making sense, I have also honed intellectual tools of survival - compartmentalization, denial, intellectualization, to wall myself off from responsibility for my actions and achieve satisfaction with my "responsible" green behavior, allowing me to do everything I can short of inconveniencing myself and my lifestyle. The authors of A Book of Ecological Virtues have gently but firmly challenged this attitude, found and confronted the weaknesses in this delusional thinking, and invited "a serious moral reckoning with the damage we have inflicted and continue to inflict upon the living world" (Christie 2020, p. 138). This is the beginning of "the work of renewing our ethical relationship to the living world" (p. 137). 


\section{Situating (hu)man(s)}

Throughout much of the Cenozoic - the age of mammals - humans and humanoids have been survivors, eking out a living in the context of a planet with a full cast of organisms each bent on surviving, thriving, and reproducing as best it can. The Anthropocene epoch, however, has seen humans begin to have an outsized impact on the biosphere, the geosphere, and the atmosphere, and we are beginning to make ourselves known in the extraterrestrial territory that we have been able to reach. Note: The most recent division of the geologic timescale is known as the Holocene epoch which commenced at the end of the last ice age, about 11,700 years ago. The Anthropocene, an unofficial epoch, refers to a suggested geologic division characterized by the advent of humans' ability to significantly alter Earth's atmosphere, biosphere, and geosphere (Crutzen 2002). Proposals have placed the beginning of the Anthropocene anywhere between 2.5 MYBP to the 1960s (Crutzen and Stoermer 2000). For the purposes of this discussion, we will be concentrating on post-industrial revolution Earth.

Humans are a tenacious species. We have remarkable tolerance for less-than-ideal situations. We have expanded our habitats from the fertile African grasslands of our origins to the driest deserts of Africa, Asia, Australia, and the Americas; the arctic; high altitude mountain environments, even above the tree line; and isolated islands at all latitudes. In each, we have found ways to exploit whatever resources are available and live-generally in intricately interdependent dynamic equilibrium with other living and non-living things - in ways that satisfied us to the extent that we have nearly always gone beyond survival to produce art and to enact culture-in short, to make our lives meaningful. As humans began to go beyond merely eking out an existence, we were able to exercise more and more control over our environments, to dominate them in some ways, and to desire and accumulate more than we needed-a trait which Jan Zwicky (2020) suggests might be "the defining characteristic of North American and other post-colonial cultures," (p. 59) but likely is indicative of some more fundamental and widespread characteristics of our species.

The necessity of caring for our environment, never much of an issue while we were simply an unnoteworthy part of it, began to play out in what might now uncontroversially be characterized as ecological damage - we gave birth to the very idea of pollution. Few other organisms even those that alter-even radically alter-their environment are considered polluters, yet humans knowingly and severely pollute our immediate and greater environments in the name of progress and "the-right-to" even when we can find practical and sustainable ways to live more harmoniously with our surroundings.

\section{Organism | environment}

The construction organism I environment is meant to indicate a dialectical relationship between individual organisms and the environment of which they are a part. It signifies that each member of the pair presupposes the existence of the other and is, in fact, dependent upon it.

In grappling with the question of why/if we, as humans, should/must address environmental issues (both local and global) created or exacerbated by human activity, the question can be framed in terms of whether our activity matters in the very long term 
and whether consideration of our responsibilities to ourselves, future generations, other organisms, and the earth itself is warranted.

The relationship between each of us (as a representative of all of humanity) and the earth, both as a whole and its various habitats and ecosystems is, at the very least, contested. On the one hand, awareness of oneself as a reasoning, sentient organism should endow one with a responsibility (or, if one chooses to dodge that responsibility, a measure of guilt) for others, both human and non-human; living and non-living. On the other hand, all life is self-centered-driven to survive, thrive and reproduce. Why should we expect anything different from humans? Should we aspire to the examples of interaction and interdependence provided in the natural world? Should we use the natural world as a model for our own ways of being? Or should we simply live, motivated by security, survival, acquisition, pleasure, and myriad other drives that guide human behavior, leaving time and the system to deal with the consequences?

\section{One for all, all for one?}

Sonja Geiger, Siegmar Otto, and Ulf Schrader, (2018) make a case that individuals' efforts to improve their own health and well-being may result in behaviors, actions, and "sideeffects" that contribute to environmental well-being - what the authors refer to as indirect co-benefits. I suppose this should not be a surprise. Assuming that humans are integrated into a complex and radically interdependent system, if we nurture ourselves as individuals, and if we care for $u s$ as a species, we nurture the system ... and it nurtures us. Of course, this is not to say that what we determine is good for us really is good for the system as a whole. Humans do not always behave harmoniously within either social or natural frames of reference. Thierry Long, Damien Bazin, and Heesoon Bai (2018), in an examination of outdoor recreational activities often touted as somehow supportive of nature and the environment, suggest that the slow, potentially contemplative activities such as trekking are consistent with the what's-good-for-the-individual-is-good-for-the-environment paradigm while fast-paced activities such as whitewater sports are not.

Wolff-Michael Roth (2021, this issue) explores the blurry, muddy, or non-existent boundaries between humans and other parts of our environment (organisms as well as inorganic components):

The psychologist and philosopher William James (1909) proposed that we theorize using a live organism and its organs as a metaphor: "as we are ourselves a part of the earth so our organs are her organs" (p. 159). In an organismic ontology, the subject and its environment are thought of as what they are: living, thus continuously changing parts of a single organism. They are interdependent parts, such that "the body is part of the environment for the part, and the part is a portion of the environment for the body" (Whitehead 1926, p. 185).

If we think of ourselves and Earth not as separate but, instead, as dialectically related entities, it begins to seem, to me at least, that acting out of self-interest and acting out of environmental concerns should be one and the same. My dilemma-my original wonderings about humans' responsibilities to consciously act on behalf of the environment-is that this stance does not seem to demand any action (or inaction) on our part. Yet, the current state of much of the earth indicates that human self-interest is by no means a benign or insignificant factor. 
Humans, along with other heterotrophs, are Earth's way of freeing carbon stored in organic compounds (particularly carbohydrates). Other organisms bank carbon and release oxygen. We may view the earth as an organism, a self-regulating entity of which we are a part. However, our awareness and our agency (real or imagined) create for us a dilemma. Our self-interest and the interest of the whole system, at least from our perspective, may, at times, seem in conflict. As an example, for at least the past 100 years and at an accelerating rate in more recent times, human industrial and agricultural activity has pumped more and more $\mathrm{CO}_{2}$ into the environment. Simultaneously, these same human activities have diminished forests and other habitats whose autotrophic components absorb $\mathrm{CO}_{2}$ and release $\mathrm{O}_{2}$. It seems that an integrated component of Earth systems (us) is destabilizing the equilibrium in ways that, even from our human-centered perspective, is causing severe unbalancing and damage-fires, extinctions, droughts, severe weather phenomena. Human activity is wreaking havoc with the very system of which it is a part. But how can that be? As an analogy, can our liver have different needs, wants, interests from those of our body as a whole? Our liver must function in ways that contribute to our survival or jeopardize its own existence. Of course, sometimes this is exactly the case. It could be that the entire system is moving toward a new, different equilibrium. Or perhaps there is another model that can help us to make sense of such phenomena. Could this disharmony be analogous (or, in fact identical) to cancers, autoimmune disorders, and other diseases?

\section{Glimpsing possibilities}

The COVID-19 response of nearly universal worldwide shutdown has led to beautiful, clear skies in major cities around the world (American Geophysical Union 2020). For the past several months of COVID-19 lockdown, New York City's shorelines, rivers and lakes, were bathed in and reflecting crisp sunlight reminiscent of the pristine, preindustrial landscapes that, at one time characterized this area (Sanderson and Brown 2007). Places in and around the City (and, in fact, Jersey City, Yonkers, Newark and everywhere else in the area) have looked like postcards of present city skylines that are more aspirational than actual. People around the world found that places normally shrouded in haze and smog had been clear and beautiful almost daily; for the younger ones among us, this may be the first time in their lives they experienced this. Additionally, carbon dioxide emissions dropped by as much as seven percent worldwide (Borenstein 2020).

Coming over a rise on the New Jersey Turnpike in Weehawken, the NYC skyline has the look of a picture postcard depicting a scene that lives nowhere in the world than on that glossy piece of cardstock. This may provide us with some hope that the human footprint on the earth is not as deep nor as permanent as we have come to believe. A few short months of markedly reduced emissions from factories, automobiles, jets, and other human activity related to manufacturing and energy use et voila, clean(er) air. Problem solved? Not by a long shot. But possibilities revealed? For sure.

How will we as a species process the information — data, experience, knowledge - generated by social, political and environmental crises? Bai, Chang, and Scott (2020b) remind us in the introduction to A Book of Ecological Virtues, "knowing the right thing does not necessarily translate into living the right way" (p. xii). In the past, at least during the part of my life that I have been aware of such things, the collective we-not always (not even often) in agreement on the hows-were always striving toward something better-not always (not even often) in agreement on the whats. Today, it seems that truths-absolute, tentative, provisional, aspirational or otherwise are hard to come by. In the complexity and 
contradictions of human societies, there are those who seem to be actively muddying the waters (I mean this figuratively, but it is also a literal description of the current state of affairs), making our roles as members in good standing of our world community and of ecological systems, problematic. Videos of citizens asserting their "God-given right" to breathe the air as they condemn those who, under the flag of social responsibility and protection of the public welfare, demand, or even request that they take the simple step of wearing a cloth mask while in the presence of the rest of us (particularly the more vulnerable and health-challenged in our community), indicate an apparent disregard for our fellow humans and a preference for petty freedoms over the right to LIFE asserted in the American Declaration of Independence. How much more diminished must be the regard for non-human organisms and for the planet itself? As we come to terms with COVID-19 and the economy begins to chug away again, are we disciplined enough to rethink the way we live, or will the frivolous and excessive patterns and practices return, blotting out the paradise we have glimpsed?

Over the pediment of Grant's Tomb in NYC are carved the words,

\section{LET \\ US HAVE \\ PEACE}

As one approaches the monument and begins to climb the stairs, the last word is obscured by the cornice, revealing the message:

\section{LET \\ US HAVE}

Is this what the closer look at America afforded by the ravages of COVID-19 also is showing us? Are we willing to give up peace, clean air and water, and other benefits of a reexamined society to return to our narrowly focused worship of material possessions?

The COVID-19 pandemic has made us aware of things of which we previously were unaware, even willfully unaware. It shines a low-angle light that sets in vivid relief, problems, injustices, disparities of which, again we were heretofore unaware, or that we chose to not see until the stark shadows and blinding light have left us unable to deny them. This provides us with an opportunity to rethink much about the way we live including our relationship to our environment and to our fellow earth beings. Most important, its global reach allows this for most of the world's human population simultaneously.

\section{A book of ecological virtues: living well in the Anthropocene}

Editors Heesoon Bai, David Chang, and Charles Scott along with nearly two dozen authors of A Book of Ecological Virtues: Living Well in the Anthropocene (2020a) make a strong, multivoiced, case for human responsibility for the fortunes of themselves, their fellow earth inhabitants and for the earth itself. This truly is a transformative book-not so much for the truths it imparts, but for the complexity, contradictions, dissonance, and harmony the reader experiences as she engages with chapter after chapter. To be sure there is guidance, and explicit strategies are proposed. But it is the overall universe of 
ideas that the contributors and the reader co-construct in the reading and in the post-read pondering that is the real payoff for authors, readers and, I am confident, the earth itself.

It is likely that all who read this book will come away knowing the world and their roles in it differently, acting in a more purposeful, more thoughtful way vis-à-vis the environment. Will this solve all environmental and societal problems? No, it won't. But it is a start. Perhaps, like a ratchet that moves in one direction and clicks, preventing backward motion, the seeds planted by the authors of this book will move us in a right direction that will be hard to retreat from.

The authors, together and separately, and always in conjunction with the reader, weave a narrative that is at times hopeful and at times dark and pessimistic - sometimes both at once. However, the truths they reveal, chapter by chapter, resonate with each other and with the reader in the construction of a manifesto for a future of harmony, fulfillment, and survival that draws on, cuts across, and encompasses a variety of knowledge and belief systems. It treads ground which all who pick up this book may find familiar and comfortable; all who finish this book will find their ken expanded so that there is much more accessible ground than when they began.

The authors offer not quite prescriptions, but illumination of approaches to inner, outer and transactional harmony. How do we become part of something bigger, modify our behavior to reflect that, and help others to be part of a movement toward not-destructive relationships with each other and the rest of the natural world?

Each chapter stands alone as a valuable statement and a provocation toward a deeper understanding of our relationship to the environment. The chapters don't speak to any one of us in the same way or to the same degree, but, in concert, they (in collaboration with the reader) provide a solid body of thinking from which to launch intellectual and physical action.

The title A Book of Ecological Virtues: Living Well in the Anthropocene demands a consideration of what the authors, and more important, what we consider "virtues" and how we define "living well." David Loy (2020) in his contribution to the book asks us to consider.

What makes an act morally significant? There are many ways to respond to this question, but three different accounts are the most popular: consequentialism (are the results good or bad?), deontology (does it accord with moral laws?), and virtue ethics (what would a virtuous person want to do in that situation?). (p. 118)

Here, we are confronted with words that speak to each of us differently: good, bad, moral, virtuous. Perhaps a working definition of virtue (also laden with problematic language) will allow us to move on for now. Virtue is action in response to a sort of knowledge/ sense of what is right - a moral smartness. One way to make and follow a virtuous path is to imagine what is right and take corresponding (or, at least, congruous) actions. Always reassess. When mistakes are encountered not only acknowledge, but learn from them and deploy new, transformed behavior.

Even awareness of the peril in which we have put the earth and its creatures, acknowledgement of our responsibility for it, and the imperative to do something to mitigate our impact are examples of our chauvinistic anthropocentricity. Who are we to assume power over, and responsibility for, the condition of the earth and assume that the earth is incapable of making the necessary adjustments (including shaking off those creatures that are detrimental to the system)? Who are we to place ourselves outside of, or even above the system? 
A Book of Ecological Virtues explores critical issues in human-earth system relationships - the rights and responsibilities of being a human sharing a planet with other beings and materials. It, refreshingly, addresses these things drawing on an eclectic mix of knowledge systems enabling complementarity, complexity, and contradiction to inform our unfolding understandings of the "reciprocal relationships and responsibilities" (Turner and Matthews 2020, p. 6) among all life forms and the materials of earth. It also pushes back against the comfortable and all-too-common monosemic, internally consistent "understandings" encountered when addressing environmental issues in the context of human progress. Each chapter complements and challenges the others, ultimately leaving the reader's awareness heightened and broadened, and the reader more prepared to make beneficial changes to self, community, and world.

\section{Cycles of materials, energy, life, and death}

That the earth is a highly complex system of interconnected and interdependent elements is not a radical or even controversial statement. But what constitutes the elements, their relative importance, and the benefits, rights and responsibilities associated with this knowledge all are highly contested-ontologically and axiologically. We have addressed human, more-than-human, post-human, secular and religious, Eastern, Western, and Indigenous perspectives on these matters in this special edition of CSSE as have the authors of A Book of Ecological Virtues. We now turn briefly to the system itself.

Adherents of many knowledge and belief systems appreciate that materials and energy move through space and time in ways that are not always predictable, but understandable and having some degree of regularity. The Western lens centers the conservation and transformation of matter and energy and the perpetual cycling of materials in nature. Religions and other knowledge systems additionally assume the presence and cycling of less tangible elements of nature and spirit.

Death is absent from much discourse on environmental issues except in the sense of tragedy, loss, habitat destruction and extinction resulting from exploitation and poisoning of the environment (Greenwood and McKee 2020). The cycles and rhythms of nature allow us to consider the death of an individual, a species, or an environment not as a tragic end (even when it is a tragic end), but as a necessary, inevitable process in the functioning of the systems of the world.

Many of us seek to ignore, deny, or delay our own mortality and impending demise even as we are "hell-bent on ecological destruction" (Greenwood and McKee 2020, p. 72) - the devastation and death of habitats and species - as we act on "values that treat the earth as an object to be exploited for notions of human progress" (Scott, Behrisch, Bhattacharjee, Grass and Bai 2021, this issue). Acceptance of death as part of the complexity of existence and, in fact, death's elevation in our estimation of the marvels of life and living is an ecological virtue that can contribute to ways of believing, being, and becoming that honor and benefit humans, other organisms and the environment.

Bai brings palpable clarity to this notion in her very personal encounter with and account of her father's death and return to the soil (Scott et al. 2021, this issue) in what she refers to as "the great cycle of creaturely life and death." Bai, as well as David Greenwood and Margaret McKee (2020), locate death not as an endpoint but as an essential component of the unfathomably interconnected, dynamic, complex earth system within which we all are dialectically, or perhaps more accurately, multilectically (Fellner 2015) entwined. 


\section{Many voices: many perspectives—one complex, omnipresent crisis}

Multiple belief/knowledge systems have similar or compatible views of eco-virtuismbehaving in sustainable ways that respect the planet and its inhabitants. Many of these systems have existed for millennia. They have demonstrated their viability and longevity. David Loy (2020) claims that these approaches to right living are "especially important today, because they are the kinds of virtues that are needed in our time of ecological crisis" (p. 118).

Is this a time of particularly acute "ecological crisis"? Was the industrial revolution? The arrival of Europeans in the Americas? ...in Australia? ... in (insert geographic location here)? Widening the frame and the time scale, was it a crisis when the proliferation of autotrophs pumped previously unmatched amounts of oxygen into the atmosphere, rendering it unfit to support many of the then existing life forms, leaving "an entire biosphere that did not survive in the oxygen-rich environment that later developed" (Zimmer 2013) and, in fact, making the atmosphere itself flammable - a circumstance that today manifests itself in massive fires in Australia, Indonesia, the American West, Siberia, and other parts of the world that consume extensive forest areas and their inhabitants (Hess 2020)? These questions are worthy of discussion, but it is unlikely that they will lead to a consensus on any course of action we might take in response to current environmental concerns. So, let us assume for now, regardless of precedent, that unnecessarily addressing a not-very-serious problem, particularly if our efforts at mitigation yield beneficial collateral effects, is preferable to failing to take action to repair a very critical situation.

\section{A two-way street}

Nancy Turner and Darcy Matthews (2020) observe that, in Western traditions, "humans represent the pinnacle of life, and that through this special status we can rightfully use any and all of earth's resources for our own ends. This attitude determines, largely, our behaviours and actions" (p. 3). But how do we reconcile behaviors and actions that, ultimately, lead to the demise of humanity, endangerment and extinction of other species, and radical alteration of habitats? Does this negate our right to do with the earth as we will? Can we imagine a paradigm where humans relinquish the idea of dominion and embrace responsibility for stewardship of the environment? What are the implications for human behavior of the stance, promoted by the rights of nature movement, that humans are one among the world's species all with legitimate claims to suitable environmental conditions?

\section{Is ecological virtue selfish?}

Does selfish behavior (and I mean selfish not in a pejorative sense, but in the sense of self interest with an eye toward survival) in the context of a radically interdependent self-regulating earth system automatically lead to ecological virtuousness? No being can conceive of the complexity of the entire system, of how each action will mediate the energy, materials, and relationships between the elements of the whole to make fully informed, rational, viable decisions about doing "good" in the world. Therefore, if all organisms act merely on needs and wants, and respond consciously or unconsciously to feedback in the interest of satiety, survival, satisfaction, and procreation, will that be sufficient for the entire system to self-regulate? 
Turner and Matthews (2020) question the commonly held one-way notion of ecosystem services - the benefits humans derive from the environment. They advocate "completing the ecosystem services circle by including human environmental responsibility and emphasizing the virtue of human services to nature-a notion common in many Indigenous cultures. This is particularly critical as, in a human need-centered ecosystem services analysis, "humans are consuming 60 percent over what the global ecosystem is able to sustainably provide" (Falkenberg 2020, p. 157). Michael Pollan (2006) discussing the relationships between humans and the living things that they have cultivated and domesticated raises questions about who domesticated whom. Specifically, he explores human-canine and human-grain relationships from the dog and corn standpoints. Firmly embedded in Western traditions, Pollan asserts that we cannot frame human relationships with the earth and its beings without recognizing — or at least considering — their agency, their needs, and their contributions to our well-being. We can consider humans' relationships with the earth and all its beings using any number of system models that decenter humans and respect the planet and all of its life forms in ways that ultimately will benefit the entire system, including humans (Falkenberg 2020).

In this paper, I have been grappling with the kinds of changes required to preserve, improve, and reverse the adverse effects of human behavior on the state of our planet. I have argued both for substantial systemic change and for modification of personal behaviors. While these are often pitted against each other by those concerned with large ecological health issues, I see them as compatible, perhaps interdependent conditions for the kinds of ecofriendly, eco-virtuous attitudes and behaviors called for here. Pollan (2008) in a critique of the film, An Inconvenient Truth, describes his horror at "the puniness of what [the film] was asking us to do" when, after laying out an apocalyptic view of a future where global warming is left un- or inadequately addressed, we are asked to take actions such as recycling our plastics and turning the thermostat down. However, it seems clear that more systemic action on a scale that only governments and international organizations can affect is necessary, but, on its own insufficient without awareness, a sense of empowerment, and the collective power of small-scale personal action fostered by a perception of personal responsibility.

\section{Indirect virtues}

Geiger, Otto, and Schrader (2018) provide evidence that mindfulness and behavior in the service of personal health encourage personal behaviors (diet, exercise, etc.) that indirectly result in actions and practices that support a healthier environment. They further suggest that the pursuit of more healthy lifestyles results, however modestly, in increased ecological behavior that goes beyond personal health benefits and propose a greater presence of mindfulness and personal health in science education. While the magnitude of these indirect effects may be small, mindfulness practices may have the effect of reattuning practitioners with their connections with and roles in the complex system(s) that comprise(s) Earth, ultimately resulting in social and political support for sustainable approaches to environmental issues.

Sophia Jeong, Brandon Sherman and Deborah Tippins (2021, this issue) explore the role science education might play in producing a science literacy that can lead to sustainability. They challenge the place of humans as above or apart from nature, decentering humans and reframing us as part of the community of all living things. Jeong and her colleagues consider humanity's "entanglement with the world" and propose "conceiving of 
a scientific literacy that calls for a more complex understanding of this world as a multilayered, ecological community consisting of inter-dependent, relational, co-constitutive becomings." Wolff-Michael Roth (2021, this issue) also proposes a perspective that reintegrates humans into a more equitable place in the biosphere and focuses on the constant becoming or flux in the relationships between and among living things. In his conception, organisms are decentered as he focuses on flux - change as elements in the complexity of the earth system interact. Flux is both the product of interspecies interactions and the progenitor of further flux. Flux itself is in flux.

Paul Crowe (2020) in his consideration of Daoist virtues expands the discussion beyond inter-organism relationships. He breaches the living vs. non-living paradigm, elevating what are considered in many knowledge/belief systems as abiotic factors in the environment (water, air, etc.) to parity with the earth's organisms. He acknowledges that "anyone advocating a deep and pervasive change in perspective on the relationship of human beings to the ecological fabric that sustains them faces a daunting challenge" and "what we consider the moral sphere is expanded radically to dissolve a clear distinction between the human and the cosmic" (p. 108).

However small the effects of any one person's more ecologically virtuous behavior on the environment, or even the cumulative effects of such efforts, the true value of incorporation of mindfulness, personal health and eco-virtues into education-in science and all other areas-is that they can contribute to awareness that may provide support for and adherence to the kinds of large-scale actions required to mitigate and ameliorate the impact of humans on climate and other global ecological concerns. Derek Rasmussen (Akulukjuk, Erkaeva, Rasmussen, and Martusewicz 2020) captures the aspirational spirit of individual responsibility and individual action when he encourages us to live and act as if we already had the revolution that produced the world in which we wish to live: "Think of the ways we cultivate rootedness and responsibility to landscapes and to each other and foster joy and creativity. Now go do them" (p. 251)!

\section{Creativity and ecological virtue}

Artists, writers, performers, and other individuals we label as creative are in the business of co-constructing the world in collaboration with both the world and the consumers of (or, when most successful, partners in) their efforts.

The agrarian philosopher and writer Wendell Berry (2002) captures the dispiriting sense of powerlessness in the face of a goal seemingly too big to achieve when he speaks about the "odd experience" of continuing to write for decades "essays and speeches that one would prefer not to write, that one wishes would prove unnecessary, that one hopes nobody will have any need for" but sounds a more optimistic note: "I have never doubted for a minute the importance of the hope I have tried to serve: the hope that we might become a healthy people in a healthy land." As it is for Berry, among the practices any of us with the ability and inclination can do is write. Writing does not conserve fuel, clean the air and water, or protect endangered species. However, writing enables us as scholars, educators, policy makers, and citizens to wrestle with our own understanding, and provoke others with our ideas. Among the efforts we make to diminish our footprint and to lessen our negative impacts on the environment, "[t]o think and rethink such matters, and to write and rewrite might itself be, in some small way, ecologically virtuous" (Jardine 2020, p. 202).

Doom and gloom characterize much discourse on environmental issues. While it can be argued that this is a realistic approach to the urgency of environmentally damaging 
practices and policies, it also can have an overwhelming, paralyzing effect on us. If we frame our connections with the world only in terms of danger and disaster, we risk provoking despair, hopelessness and, ultimately, anger, resentment, and, above all, inaction. In a more nuanced approach, as we co-create the world with the world, we may/must "speak our world, in all its magical and terrifying complexity, as if it is a place of love" (Leggo and McKeon 2020, p. 253) and find "new ways of knowing, being, becoming, doing, and hoping” (p. 254). All of us-producers, consumers, and partners in creating across all domains and knowledge systems-in order to ceaselessly (re)orient and (re)commit ourselves to responsible, aware, eco-virtuous behavior, must

explore how to live well by engaging together in a braiding of poetry, stories, and ruminations that attend to our nurturing of loving relationships [...] sustaining wellbeing through consciousness, composure, and connection. (p. 255)

\section{A case for diversity}

Diversity (of belief, expertise, demographic category, personal history, profession, etc.) provides us with multiple ways of making sense of the world. A Book of Ecological Virtues embraces difference. The beliefs, values, experience, and backgrounds of the authors contribute to a complex, multidimensional meaning making about our world-internal and external, physical, intellectual, and spiritual. Any serious attempt to address the challenges we and the world of which we are a part face must be informed by such a multiplicity of voices. We must employ individual responsible action, apply scientific approaches to tackle the small but important slice of the world they can address, construct and realize political solutions to bigger systemic problems, and tap into local, traditional and indigenous knowledges that draw on intimate, direct and long-lived understandings of the world, with the world. Inclusiveness and diversity are not merely niceties for the benefit of one disenfranchised population or another. They are an essential part of any earnest attempt to move toward a dynamically sustainable future that benefits the human lot in a more-than-human context. And current environmental and social issues are something about which we must be earnest, if not desperate to ameliorate, mitigate, and remedy.

\section{A case for a broader view of education}

Schooling, often considered synonymous with educating, is most often conducted in classrooms - rows of desks or clusters of tables arranged to focus some or all attention on a teacher some or all of the time. This "decontextualize[s] learning [from the everyday life of the learner] and recontextualize[s] it in a contrived environment that is, at best, a diminished simulation of the 'real' world of the learner" (Bleier 2021, p. 46). Technological innovations have been embraced in formal education as they have in the home as increasingly essential to enhance both learning and living. Such technologies have, "in ways both subtle and significant, asserted the terms of our tenure as a species on the planet, and we have, in turn, become the subjects of our technological apparatus" (Chang 2020, p. 217). So, we see that the simplification of the classroom environment in the name of easily digestible knowledge acquisition and the modern enhancements of technology combine to decenter and diminish the status of the learner and the world itself in favor of the curriculum. However, the importance of the often invisible, informal, in-the-family and in-the-world education we receive cannot be overstated. Being in the world (particularly 
the natural world) allows the world to educate us, to draw us in, to enhance our understandings of the planet and of ourselves in new, broader, more nuanced, and inclusive ways. It stokes our sense making in both concrete and intangible ways. In the family and in the community, we also learn "lessons of kindness and caring for other creatures," for our fellow humans and for the environment (Akulukjuk et al. 2020).

Ecological presence (Kahn 2020) — "an experience of perceptions that can emerge through interaction with nature, wherein those perceptions can then settle into a mind's awareness without conscious mind activity" (p. 32)—is at once conscious and unconscious and both emerges from and is enhanced by time spent in nature. It should be a goal of formal and informal education and can only be affected by time and effort spent in the natural world.

The idea (at least the spirit) of ecological presence is not new. However, it is easily marginalized in the ebb and flow of demands of time and expense in formal education settings. The nature study movement of the late 19th and early 20th centuries saw the collaboration of scientists and educators to infuse both formal and informal educative practices with time spent by learners in the natural world. Their efforts included prescriptive curricula as well as exposing learners to the joys and benefits of simply being and studying in the natural world (Kohlstedt 2010). The nature study movement's guiding principle: "study nature, not books" smacks of Cartesian dualism and would benefit from a more tempered, nuanced treatment as there is a far more "complex and complicated relationship of biophilia [love of nature] and bibliophilia [love of books]" (Bai, Elza, Kovacs and Romanycia 2010), particularly in the domains of academia and science education. The contested but alluring concept of nature-deficit disorder also recognizes the importance of (re)connecting the learner with the natural world (Mitchell, Tippins, Kim, Perkins, and Rudolph 2016).

In their contribution to A Book of Ecological Virtues, Tommy Akulukjuk, Nigora Erkaeva, Derek Rasmussen, and Rebecca Martusewicz (2020) explore the subjugation, othering, diminishing, mischaracterization, and misunderstanding of traditional, Indigenous, rural, land-based knowledge production by forces of capitalism and colonialism. Their personal stories are a polyphonic, polysemic exploration of land-based knowledge production that together form a complex, euphonious symphony of cultural production on the margins of a radical, rapacious, and hegemonic manifestation of progress and modernity. They don't so much reject or call for the eradication of outside forces bent on dragging their worlds into "the present" (although sometimes they do just this), as make a case for allowing their own ways of knowing, learning, and teaching to coexist, to contribute, to have a place at the table of possibilities for how to live here and now in the Anthropocene.

Erkaeva recounts childhood memories of leaving her city for long summers spent in her grandmother's village in rural Tajikistan. Outside the confines of modern schooling practices, she engaged in the day-to-day activity of a working farm. There, she not only learned in practice the care of animals and the respect for and upkeep of village and farm resources, but the responsibility to family and community necessary for the entire enterprise to function. As an adult, she recognizes her limited understanding of the significance of the teachings she received from her grandmother, mother, and other members of her community that now form "the main pillars of my understanding of the world" (p. 242). She concludes:

...we need an education that teaches us the humility to recognize ourselves as a part of a bigger ecological system upon which we depend emotionally, physically, economically, and socially; education through which we learn that we are one member of a complex web of life, and that our responsibility is to take care of this complex web of the common good. (p. 242) 
Akulukjuk writes of modern education devaluing and disrespecting the knowledge and wisdom of the elders of his small Nunavut village. The community, family, and environment from and within which he had learned everything was marginalized by the formal schooling imposed on him from the outside. He observes that the knowledge and wisdom associated with everyday life in his village found no place, no voice in the classroom. They were considered things of the past even as they continued to be necessary for everyday survival in the present. He illustrates the disconnect between two modes of educating:

Inuit don't really have a word for smart. The closest thing I can think of is silatujuk which can be roughly translated as one who is conscious about his whole environment and responds to it calmly. He understands his world. [...He is in] some way an enlightened person. This word silatujuk comes with a serious sense of duty for the community, family, and friends ... (p. 236).

Rootless, placeless, "universal” and "objective," externally imposed schooling often engenders a disrespect for and a dismissal of the importance of the environment in which we live and our place in it among the other organisms, materials, and energy that comprise our world.

However, modern schooling practices are not likely to disappear or even diminish in their pervasiveness and privileged status. Those engaging in and promoting these practices must be guided or even compelled to make space for the kinds of specific and local knowledge production in which all humans engage as they live in the world, but they must also be recognized for their own intrinsic value. Tommy Akulukjuk, reflecting on his own complicated relationship with formal schooling does not reject modern education "where smartness is demonstrated by being able to perform tasks well on paper" but makes a modest suggestion that "the concept of being smart in the Inuit way should be taught, or at least tried" (p. 236).

Ultimately, no matter how we get there-through a sense of responsibility, self-denial, genuine love for our fellow creatures and our mutual home, concern for personal wellbeing, physical and spiritual considerations-it is beneficial to all if humans behave as if they are part of an integrated system which is responsive to our fellow organisms and the materials and energy that comprise the earth and the universe within which it exists. Living well is being well; living right is well-being.

When the zoologist Ernst Haeckel coined the word oecologie (ecology) he began with the Greek word оíкร (home or household) as the linguistic base of the concept the word was meant to represent and convey. If we keep this in mind as we consider the words derived from Haeckel's original construction-ecofriendly, ecosystem, ecoterrorist, ecovirtue-we see these things and our relationship to them in very different ways. Earth is our home, a home we share with others. We don't question our responsibility for the upkeep of the shelter that provides us with a place for refuge and the physical, emotional, and spiritual activities in which we engage there, nor do we question our responsibility to the others that share our homes with us. To be sure, we sometimes come into conflict with our cohabitants and we do not always make the best choices about what we do in and to our physical surroundings. However, we are more aware of and more thoughtful about our homes than we are about our neighborhood; we are more aware and thoughtful about how we treat our neighborhood than our town; more aware of our town than our state, province or prefecture; etc. until we lose track of our relationship to our continent, our planet, and our universe. We have a self-interest if not a responsibility to make the effort to be more aware, and consequently more thoughtful about the wider and wider structures of which we are a part, and we have the responsibility to provoke the same behavior in our cohabitants. 
However we get there, the result should the same-things will be better for everyone and everything. For this to happen, however, we must be reflective, vigilant, and ever aware. Here, an infusion of mindfulness into our educative practices can play an immeasurably vital role.

Whatever the nature of the motivations - selfish, personal, altruistic, magnanimous, righteous, obedient - we have a multiplicity of reasons for working toward more mindful, more responsible, more virtuous relationships with the world of which we are a part. Practicing appropriate ecological virtues ultimately benefits the individual and the world no matter what the inspiration or rationale for such behavior (Hannis 2020). We do not all speak with one voice, one mind, one heart. However, the effect of our collective actions, if we are to attain any sustainable equilibrium, must be to make the world a better place for the earth itself and for all of its inhabitants. Of course, better is an idea that constantly must be redefined for each of us and for the institutions and other macro structural elements that mediate our relationships with each other and with the world around us.

Just as the authors in this volume and in A Book of Ecological Virtues move from a human to a more-than-human perspective, solutions to the assault on the environment must begin with moving from the domination of Western knowledge production to morethan-Western approaches toward caring for the environment. Identifying problems and responding to them with technological solutions while trying to minimize "side effects" is emblematic of Western science and Western medicine. We need, however, an ontological shift-a view of humans as part of a complex natural-social-spiritual-ethical system-to address our world as it is, as we want it to be, and how it should be. This shift must inform education in all its manifestations-formal, informal, and that which occurs in-the-world as we go about our everyday lives.

A Book of Ecological Virtues belongs on reading lists for scientists, policy makers, educators, and learners in all fields. Its inclusion in appropriate courses of study is of vital importance. More important, however, is that as readers interact with the authors' work, they incorporate it into their own professional practice and begin to see and welcome into their professional activities the collective wisdom of diverse knowledge/belief systemsancient and modern. New generations of learners, from the earliest ages, armed with broader, more inclusive perspectives are our hope for a better, more sustainable world.

Although the eclectic collection of authors of this book is diverse in myriad ways, they all point toward a more balanced, equitable, sustainable way of living in the one world we share. As readers bring their own ways of knowing to the table, this book promises to generate ripples throughout the zeitgeist that can only support improvements-from the miniscule to the global scale - in the lot of the earth and its inhabitants. Beyond this, it is a rare combination of solid scholarship, riveting prose, and ideas that will resonate with readers and provoke ontological shifts in all of us.

This book is at once an assault on complacency, a demand for life-changing introspection, a loving embrace of humanity and the more-than-human world, and a militant assumption of the value and viability of active, relentless, critical hope.

Bai, Chang, and Scott (2020b) conclude their introduction to A Book of Ecological Virtues with their hope for the authors of the ensuing chapters: "May they inspire our readers to live the ideals of these timeless ecological virtues" (p. xvi). Well, they have inspired this reader. I am confident that the multiple voices, perspectives, knowledge systems, and moral stances that inform the work of the included authors will inspire readers to consider and reconsider their attitudes, behaviors, and actions as they live (hopefully well) in the Anthropocene. 


\section{References}

Akulukjuk, T., Erkaeva, N., Rasmussen, D., \& Martusewicz (2020). Stories of love and loss: Recommitting to each other and the land. In H. Bai, D. Chang, \& C. Scott (Eds.), A book of ecological virtuA book of ecological virtues: Living well in the Anthropocenees: living well in the Anthropocene. (pp. 233-252). Regina, SK: University of Regina Press.

American Acclimatization Society, New York. (1871). Charter and by-laws of the American Acclimatization Society. New York: G.W. Averell.

American Geophysical Union. (2020). COVID-19 lockdowns significantly impacting global air quality. Science Daily. Retrieved, August 30, 2020 from www.sciencedaily.com/releases/2020/05/20051 1124444.htm

Bai, H., Chang, D., \& Scott, C. (2020a). A book of ecological virtues: Living well in the Anthropocene. Regina, SK: University of Regina Press.

Bai, H., Chang, D., \& Scott, C. (2020b). Introduction: The call for an ecological virtue ethics. In H. Bai, D. Chang, \& C. Scott (Eds.), A book of ecological virtues: Living well in the Anthropocene. (pp. xi-xvi). Regina, SK: University of Regina Press.

Bai, H., Elza, D., Kovacs, P., \& Romanycia, S. (2010). Re-searching and re-storying the complex and complicated relationship of biophilia and bibliophilia. Environmental Education Research, 16, 351-365. https://doi.org/10.1080/13504621003613053

Berry, W. (2002). The agrarian standard. Orion Magazine. Retrieved from https://orionmagazine.org/ article/the-agrarian-standard/

Bleier, M. (2021). Learning in the world and on the job: A journey through Cheeseworld. Leiden (NL): Brill. https://doi.org/10.1163/9789004471184_001

Boissoneault, L. (2019). The Cuyahoga River caught fire at least a dozen times, but no one cared until 1969. Smithsonian Magazine. Retrieved from https://www.smithsonianmag.com/history/cuyahogariver-caught-fire-least-dozen-times-no-one-cared-until-1969-180972444/

Borenstein, S. (2020). World carbon dioxide emissions drop 7\% in pandemic-hit 2020. Associated Press News. Retrieved on December 10, 2020, from https://apnews.com/article/science-coronaviruspandemic-f23f452b2d2cbe4598223023c4d47076

Caetano-Andrade, V. L., Clement, C. R., Weigel, D., Trumbone, S., Boivin, N., Schöngart, J., \& Roberts, P. (2020). Tropical trees as time capsules of anthropogenic activity. Trends in Plant Science, 25(4), 369-380. https://doi.org/10.1016/j.tplants.2019.12.010

Chang, D. (2020). Worthy of this mountain: Living a life of friction against the machine. In H. Bai, D. Chang, \& C. Scott (Eds.), A book of ecological virtues: Living well in the Anthropocene. (pp. 117-134). Regina, SK: University of Regina Press.

Christie, D. (2020). Never weary of gazing: Contemplative practice and the cultivation of ecological virtue. In H. Bai, D. Chang, \& C. Scott (Eds.), A book of ecological virtues: Living well in the Anthropocene. (pp. 135-153). Regina, SK: University of Regina Press.

Crowe, P. (2020). What are "Daoist" virtues? Seeking an ethical perspective on human conduct and ecology. In H. Bai, D. Chang, \& C. Scott (Eds.), A book of ecological virtues: Living well in the Anthropocene. (pp. 93-115). Regina, SK: University of Regina Press.

Crutzen, P. (2002). Geology of mankind. Nature, 415, 23. https://doi.org/10.1038/415023a

Crutzen, P., \& Stoermer, E. (2000). The “Anthropocene." In Global Change Newsletter (Vol. 41, pp. 17-18). Retrieved, December 29, 2020 from http://www.igbp.net/download/18.316f18321323470 177580001401/1376383088452/NL41.pdf

Elbein, A. (2020, March 26). Pablo Escobar's hippos fill a hole left since Ice Age extinctions. New York Times.

Falkenberg, T. (2020). The ethic of sustainable well-being and well-becoming: A systems approach to virtue ethics. In H. Bai, D. Chang, \& C. Scott (Eds.), A book of ecological virtues: Living well in the Anthropocene. (pp. 157-177). Regina, SK: University of Regina Press.

Fazio, M. (2020, July 25). Your mask needs to make it to the trash can. New York Times.

Fellner, G. (2015). Multilectics and its methods. In C. Milne, K. Tobin, \& D. DeGennaro (Eds.), Sociocultural studies and implications for science education 12: The experiential and the virtual (pp. 33-58). New York: Springer. https://doi.org/10.1007/978-94-007-4240-6_2

Friedman, L. (2020, March 26). E.P.A., citing coronavirus, drastically relaxes rules for polluters. New York Times.

Geiger, S., Otto, S., \& Schrader, U. (2018). Mindfully green and healthy: an indirect path from mindfulness to ecological behavior. Frontiers in Psychology 8, (article 306). doi: https://doi.org/10.3389/fpsyg. 2017.02306 
Greenwood, D., \& McKee, M. (2020). Thanatopsis: death literacy for the living. In H. Bai, D. Chang, \& C. Scott (Eds.), A book of ecological virtues: Living well in the Anthropocene. (pp. 71-89). Regina, SK: University of Regina Press.

Hannis, M. (2020). Why virtue is good for you: the politics of ecological eudaimonism. In H. Bai, D. Chang, \& C. Scott (Eds.), A book of ecological virtues: Living well in the Anthropocene. (pp. 179198). Regina, SK: University of Regina Press.

Hess, L. (2020). World on fire 2020: Experts explain the global wildfire crisis. Landscape News. https:// news.globallandscapesforum.org/47794/fires-2020-experts-explain-the-global-wildfire-crisis/

Jardine, D. W. (2020). "Owning up to being an animal": ecological virtues of composure. In H. Bai, D. Chang, \& C. Scott (Eds.), A book of ecological virtues: Living well in the Anthropocene. (pp. 201212). Regina, SK: University of Regina Press.

Jeong, S., Sherman, B., \& Tippins, D. (2021). The Anthropocene as we know it: posthumanism, science education and scientific literacy as a path to sustainability. Cultural Studies of Science Education, 16.

Journal of the American Medical Association. (1905). Smog. In Journal of the American Medical Association, $X L V(9)$, 637. https://doi.org/https://doi.org/10.1001/jama.1905.02510090059014

Kahn, P. H. (2020). Ecological presence as a virtue. In H. Bai, D. Chang, \& C. Scott (Eds.), A book of ecological virtues: Living well in the Anthropocene. (pp. 31-48). Regina, SK: University of Regina Press.

Kohlstedt, S. G. (2010). Teaching children science: hands-on nature study in North America, 1890-1930. Chicago: University of Chicago Press.

Koyaanisqatsi. (2020). The Qatsi Trilogy. Retrieved August 11, 2020, from https://www.koyaanisqatsi.org/ films/koyaanisqatsi.php

Kremer, W. (2014). Pablo Escobar's hippos: a growing problem. BBC World Service. Retrieved September 1, 2020 from https://www.bbc.com/news/magazine-27905743

Leggo, C., \& McKeon, M. (2020). Evoking ethos: a poetic love note to place. In H. Bai, D. Chang, \& C. Scott (Eds.), A book of ecological virtues: Living well in the Anthropocene. (pp. 117-134). Regina, SK: University of Regina Press.

Long, T., Bazin, D., \& Bai, H. (2018). Environmental ethics as applied to outdoor physical practices: An analysis through the lens of Hans Jonas. Sports, Ethics, and Philosophy, 12, 194-210. https://doi.org/ $10.1080 / 17511321.2017 .1341949$

Loy, D. (2020). The ecological virtues of Buddhism. In H. Bai, D. Chang, \& C. Scott (Eds.), A book of ecological virtues: Living well in the Anthropocene. (pp. 117-134). Regina, SK: University of Regina Press.

Maher, N. (2019, June 22). How many times does a river have to burn before it matters? New York Times. Retrieved from https://www.nytimes.com/2019/06/22/climate/cleveland-fire-river-cuyahoga-1969. html?searchResultPosition $=1$

Mitchell, D., Tippins, D. J., Kim, Y. A., Perkins, G. D., \& Rudolph, H. A. (2016). Last child in the woods. In M. Powietrzynska \& K. Tobin (Eds.), Mindfulness and educating citizens for everyday life (pp. 135158). Leiden, Netherlands: Brill I Sense. https://doi.org/https://doi.org/10.1007/978-94-6300-570-8_9

New York Times (1877, November 15). American Climatization Society. New York Times.

Pollan, M. (2006). The omnivore's dilemma: A natural history of four meals. New York: Penguin.

Pollan, M. (2008, April 20). Why Bother? New York Times. Retrieved December 28, 2020 from https:// www.nytimes.com/2008/04/20/magazine/20wwln-lede-t.html

Reggio, G. (1982). Koyaanisqatsi [Film]. Institute for Regional Education (IRE).

Roth, W.-M. (2021). Gardener-becoming-tree, tree-becoming-gardener: Growing-together as a metaphor for thinking about learning and development. Cultural Studies of Science Education, 16.

Sanderson, E., \& Brown, M. (2007). Mannahatta: An ecological first look at the Manhattan landscape prior to Henry Hudson. Northeastern Naturalist, 14(4), 545-570. https://doi.org/10.1656/1092-6194(2007) 14[545:MAEFLA]2.0.CO;2.

Scott, C., Behrisch., T, Bhattacharjee, M., Grass, S., \& Bai, H. (2021). Re/turning to soil: Becoming onebodied with the earth. Cultural Studies of Science Education, 16.

Siebert, C. (2020, February 11). Letter of recommendation: Starlings (p. 20). New York Times Sunday Magazine. [Charles Siebert] Retrieved August 29, 2020 from https://www.nytimes.com/2020/02/11/magaz ine/letter-of-recommendation-starlings.html.

Teng, H., Zhang, Y., Shi, C., Mao, F., Cai, W., Lu, L., Zhao, F., Sun, Z., \& Zhang, J. (2017). Population genomics reveals speciation and introgression between brown Norway rats and their sibling species. Molecular Biology and Evolution, 34(9), 2214-2228. https://doi.org/10.1093/molbev/msx157

Todd, K. (2001). Tinkering with Eden: A natural history of exotic species in America. New York: W. W. Norton. 
Turner, N. J., \& Matthews, D. (2020). Serving nature: Completing the ecosystem services circle. In H. Bai, D. Chang, \& C. Scott (Eds.), A book of ecological virtues: Living well in the Anthropocene. (pp. 3-29). Regina, SK: University of Regina Press.

Wilcox, C. (2020, January 31). Could Pablo Escobar's escaped hippos help the environment? National Geographic. Retrieved September 1, 2020 from https://www.nationalgeographic.com/animals/2018/09/ colombia-cocaine-hippos-rewilding-experiment-news/

Zimmer, C. (2013, October 3). The mystery of Earth's oxygen. New York Times. https://www.nytimes.com/ 2013/10/03/science/earths-oxygen-a-mystery-easy-to-take-for-granted.html.

Zwicky, J. (2020). A ship from Delos. In H. Bai, D. Chang, \& C. Scott (Eds.), A book of ecological virtues: Living well in the Anthropocene. (pp. 51-69). Regina, SK: University of Regina Press.

Publisher's Note Springer Nature remains neutral with regard to jurisdictional claims in published maps and institutional affiliations.

Mitch Bleier is an independent researcher and photographer most recently associated with the City College of New York (CUNY), The Graduate Center (CUNY) and the New York City Department of Education. His work explores learning and teaching in the classroom and in the world as well as environmental issues. His latest publications are two chapters in a volume edited by Kenneth Tobin and Konstantinos Alexakos (2021) entitled Doing authentic inquiry to improve learning and teaching (Brill I Sense).

\section{Authors and Affiliations}

\section{Mitch Bleier ${ }^{1}$}

Mitch Bleier

mb626rsd@gmail.com

1 The Graduate Center of the City University of New York (CUNY), New York, NY, USA 